\title{
Prediction Study of Built Area Based Cellular Automata Modelling In Sayung Sub-district, Central Java
}

\author{
Wahid Akhsin BNS ${ }^{1}$, Fahruddin Hanafi ${ }^{1}$, Sigit Bayhu I ${ }^{2}$ \\ \{akhsin1987@mail.unnes.ac.id, fahrudin.hanafi@mail.unnes.ac.id, sigitbayhuiryanthony@ gmail.com\} \\ ${ }^{1}$ Geography Department, Faculty of Social Science, UNNES, Indonesia \\ ${ }^{2}$ Master Program in Aquatic Resource Management, Diponegoro University, Indonesia
}

\begin{abstract}
Semarang city as a center of growth in Central Java province provide a high appeal in urbanization. Areas of high density triggers the development of the area extends out of Semarang. Sub-district Sayung as the region directly adjacent to the city of Semarang get fairly significant impact of the phenomenon, it is seen from changes in land use are quite dynamic in recent years. So in this study will examine the associated changes in built area in 2005, 2009, 2015 and 2019 as well as its development prediction in 2025 in Sayung Subdistrict. The main data sources used were High-Resolution Satellite Imagery (CSRT) time series for the recording area Demak and surrounding areas, while some secondary data consisted of demographic data and some other spatial data in the form of thematic maps. Land use time series obtained from the CSRT visual interpretation to be done beforehand geometric correction on the entire image. Growth forecast and undeveloped land acquired by the raster model cellular automata using the software LanduseSim 2.0, where several parameters controller used include road networks and community centers. Results of prediction of undeveloped land in 2025 increased by 168.41 hectar of 2019 to the spatial distribution PANTURA lengthwise along the way.
\end{abstract}

Keywords: Predictions, Built Area, Cellular Automata Modelling.

\section{Introduction}

Some coastal areas in Indonesia is a place of economic activity with a high intensity that covers marine fisheries, transport, ports, mining, recreation and tourism, and the development of industrial zones[1]. High activity in the region makes environmental balance be maintained as the loss of mangrove ecosystems as buffer plants, this coupled with the growth of undeveloped land (settlements) are less controllable[2]. That phenomenon makes coastal areas appear dirty with coupled with a variety of disasters such as erosion, accretion, tidal flooding and saltwater intrusion[3] [4]. Massive land subsidence occurred mecpai 8-19 cm / year [5] [6] ,the higher the temperature increases [7], [8] stating the tidal flood that occurred in the coastal Semarang city in May 2005, has inundated about 14 villages along the coast. 
In addition to having the potential for economic development, coastal areas also have a very important function ecologically[5] [9], declares that the coastal area acts as a buffer, protector and filter between land and sea where the region has some strategic ecological functions include nutrient providers, spawning place, where the cultivation and feeding areas for marine life [10] [2]. The potential of coastal areas should be utilized to the maximum benefit to society [11],[1], Today the coastal areas of Sayung Sub-district increasingly inundated by sea water [12]. Prompting people to move to the south away from the coast [13], economic development can provide a considerable advantage but in terms of the environment lead to damage [14] which resulted in new problems in the region [11]. Supposedly land conversion in more coastal areas can be controlled by the authorities so that utilization is not compromising environmental sustainability.

Demak is a coastal area located on the north coast of Java Island that are in the path of the famous PANTURA has a very high activity[1]. In addition to its location directly adjacent to the Semarang city, which has a very rapid development in coastal areas with a predominance of industrial buildings make this area has developed very rapidly, especially in the western coast [15][12]. The presence of the port of Tanjung Emas in Semarang and some other major industry makes the region experienced over the land very rapidly. The addition of the undeveloped land provide additional load on the ground. Other activities such as groundwater pumping to meet the needs of industry and population also causes cavities in the soil which affects the intrusion and land subsidence, where the phenomenon resulted in the inundation flooding at high tide (rob). It is as it was delivered by[1] [16] where the coastal region is a region highly vulnerable to hazards such as flood inundation and land subsidence [17] [18]. Increased undeveloped land evolving impact on environmental degradation due to land that was originally used as conservation land converted as productive oriented economic sectors so that the need for restrictions on development in the region. Required an analysis associated with changes in land use that occurred in the study area to determine how much of industrial areas in the coastal Semarang city has an impact on development in Sayung Sub-district which can lead to degradation of the environment[19].

Undeveloped land change analysis is very useful in determining the policy [20], development of the region is a key issue in a variety of highlights from experts planning[7]. Remote sensing is efficient in detecting packet in multi-temporal changes[21] [22] [23], remote sensing data is used as reference in the predicted direction of the development in the year - next year [20] [24], The combination of GIS and remote sensing allows the presentation of data that is capable of mapping the prediction and mapping of the area awakened[23] [22].

\section{Research Methods}

This research was conducted in the Sayung Sub-district coastal region, as the region directly adjacent to the Semarang city on the east. Sayung Sub-district coastal areas are most affected areas of activity of the Port of Tanjung Emas. The impact of the reclamation which lead to damage such as abrasion coast [12] acroding almost all the coastline, resulting in the RT population should be relocated to a safer place[13]. In addition rob also a phenomenon that often occurs up to this time, even if the tide is high enough water can rob to get into settlements [25] [26]. The main data sources used are high-resolution satellite imagery Digital Globe time series of data provider of open source, where high-resolution image recording used is a 2005, 2009, 2014 and 2019 for 
recording region Sayung Sub-district and surrounding areas. Furthermore, some of the supporting data used include: roads and community centers all of which are in the form of digital data, while the other supporting data is the demographic data in the last period.

Data processing stages starting from the preparation of maps of land use imagery sourced from Digital Globe, where the initial stages starting from the pre-processing image geometric correction by the method of image to image [19] [27]. Stages of this correction is done with the aim to put back in accordance with the original pixel values[27] [19] [14] [28]. Furthermore, after the entire image corrected interpretation geoemtric next step is done visually to obtain an overview of land use in time series, the selection of visual interpretation methods in order to obtain a map of the land use study site in more detail[28]. Furthermore, from land use maps of the time series analysis of the changes made to each class, in which the results of the analysis that will be used to predict the development of undeveloped land for the next few years, of course, also consider population growth data within a certain time. Preparation of maps and undeveloped land development predictions based on the model of cellular automata raster by utilizing LanduseSim 2.0 software, [20] where there are several controller parameter distribution and undeveloped land development consists of a network of roads and community centers. 


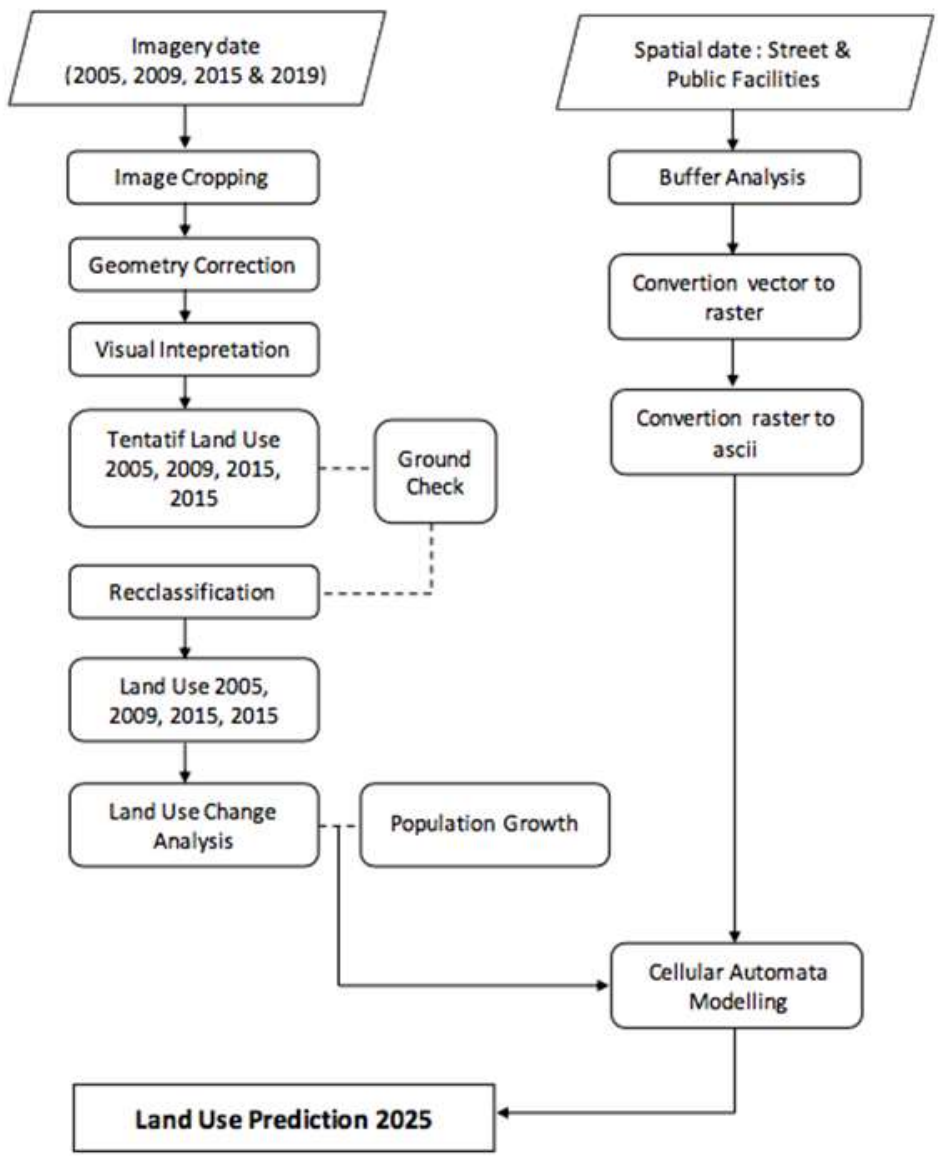

Figure 1. Research Flow chart

\section{The Results and Discussions}

Visual interpretation of the results, provides an overview of the existing land use are classified in 9th grade. Most of the area is dominated by the use of the Sayung Sub-district Fishpond area of 4417,10 hectar land where the pond is a type of fish and shrimp ponds are managed by the local community with traditional methods. The rice field has 1096,70 hectar which has a spatial distribution in the north. Built area has an 1131,80 hectar (residential and non-residential), where the settlement discount pattern that extends all the way PANTURA and most follow the flow of a river that has a spatial distribution almost evenly across all locations. The use of mangrove land 
has an area of 297,20 hectar distributed lengthwise in the dike embankment and clustered along the shoreline. In complete types of land use in the study site in Table 1.

Table 1. Land use distribution in Sayung Sub-district

\begin{tabular}{lllll}
\hline landuse & \multicolumn{2}{l}{ Area (hectar) } & & \\
& $\mathbf{2 0 0 5}$ & $\mathbf{2 0 0 9}$ & $\mathbf{2 0 1 5}$ & $\mathbf{2 0 1 9}$ \\
\hline built area & 905.8 & 944.6 & 1099.1 & 1131.8 \\
Roads & 14.3 & 14.29 & 14.3 & 14.3 \\
River & 202.8 & 202.8 & 202.8 & 202.8 \\
Mangrove & 95.3 & 58.0 & 258.1 & 297.2 \\
Fishpond & 3711.0 & 3774.9 & 3836.3 & 4417.1 \\
Mixed garden & 380.4 & 328.6 & 215.4 & 158.7 \\
Rice field & 1873.0 & 1941.0 & 1630.8 & 1096.7 \\
open field & 118.7 & 171.6 & 201.9 & 145.2 \\
Vegetation non mangrove & 567.3 & 433.1 & 410.2 & 405.1 \\
\hline Total & $\mathbf{7 8 6 9 . 0}$ & $\mathbf{7 8 6 9 . 0}$ & $\mathbf{7 8 6 9 . 0}$ & $\mathbf{7 8 6 9 . 0}$ \\
\hline
\end{tabular}

Source : Digital globe imagery precessing, 2019

Land use in Sayung Sub-district within the last 14 years has developed quite dynamically, where one of the factors that influence the phenomenon is the growing industrial sectors in the coastal area of Semarang [13] [4]. Land use has increased quite significantly is a pond with an increase of 705.9 hectar, the increase caused by the extensive pondabrasion occurred in the last few years which resulted in some of the houses should be relocated so that the land used for farms [13]. Spatial distribution of pond area extends along the coastline, with the movement of abrasion to the south is getting closer PANTURA, it is also supported by research methods NDWI (Normalized diffrent Water Index) performed by [12].

Furthermore, there is undeveloped land which increased by 226.01 hectar, which amount is comprised of residential and non-residential. The vast increase will increase the pressure on the soil surface which will further depress the soil and rocks beneath so may result in land subsidence [5] [6] [29]. That phenomenon will lead to rob because it allows sea water is higher than the plains [30] [26], any other use that has increased is the extent of mangrove ecosystems, which from the year 2005 - 2014 in the coastal mangrove Sayung Sub-district increased about 201.84 hectar. The addition of the result of the mangrove planting programs conducted by several parties, both of stakeholders and private with a model of community empowerment. Mangrove planting with patterns clustered along the shoreline, hopefully with the pattern more to prevent abrasion.

One of land use decreased paddy area is agricultural land, which in the period $2005-2019$ was reduced by 776.48 hectar. One cause of the reduction in the fields due to increased need for land for housing so that going over the land of the use of the land. The limited paddy fields have an impact on the decrease of agricultural production so that if this continues in the long term could 
lead to a food crisis. The following figure presents the trend of change in land use in the Sayung Sub-district from 2005 to 2019.

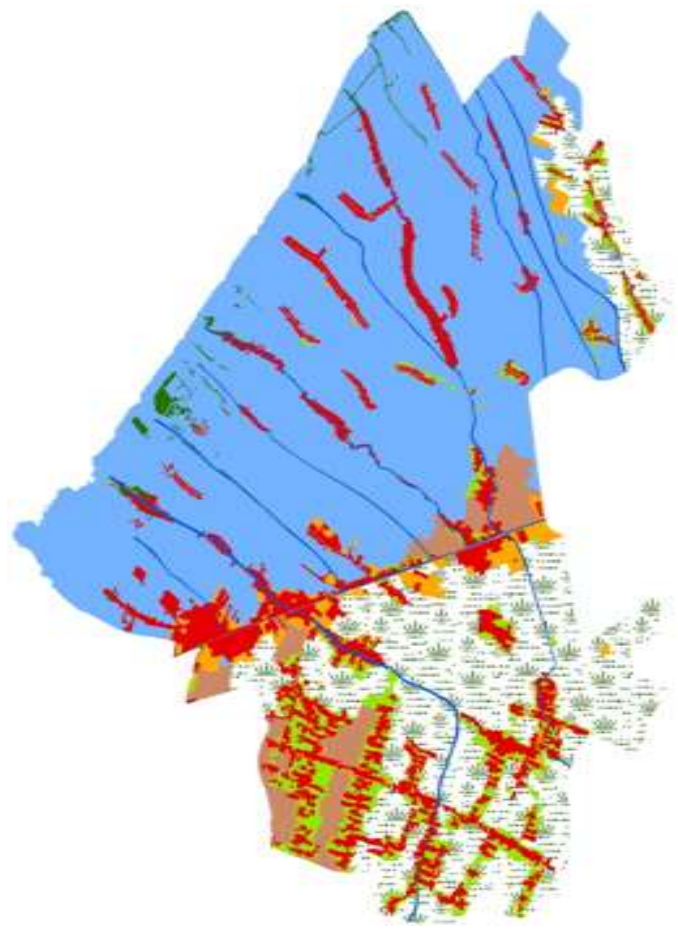

(a)



(b) 


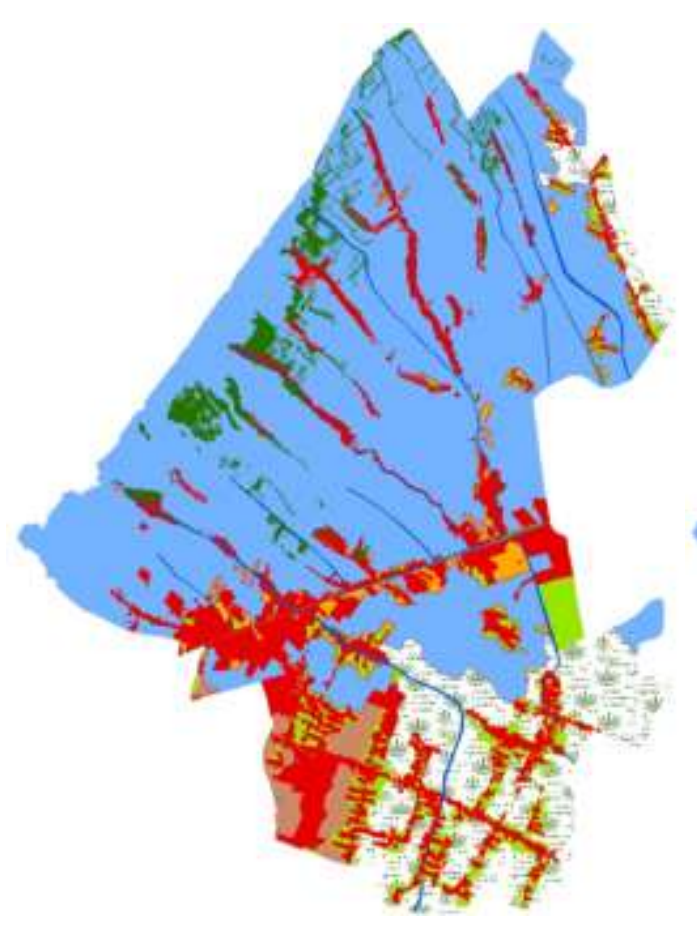

(c)

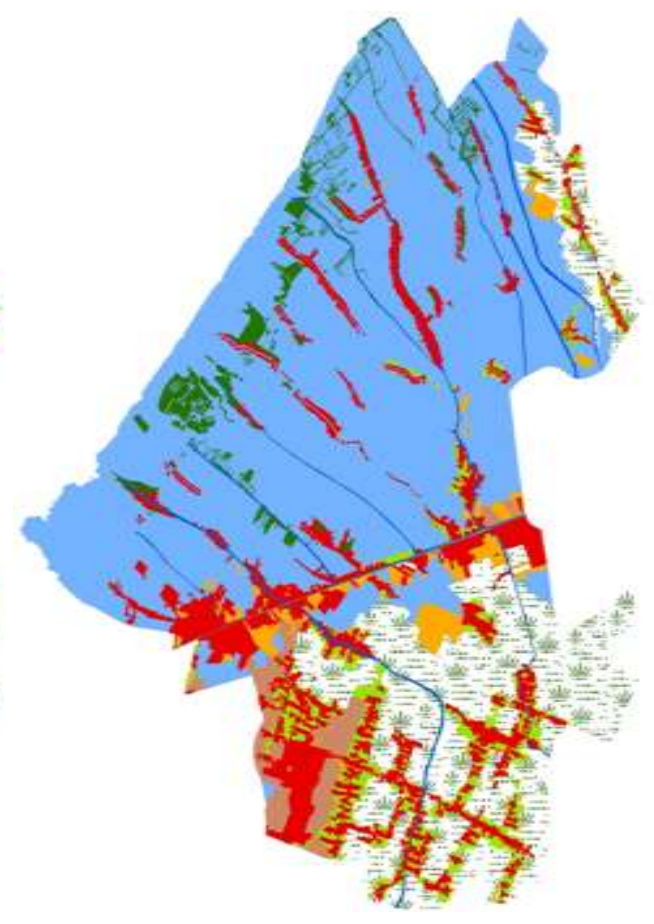

(d)

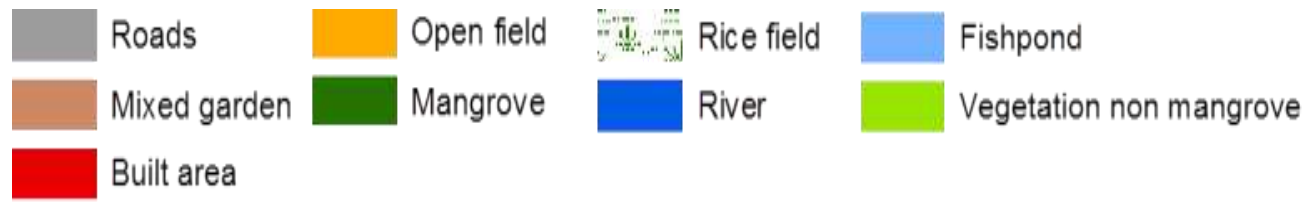

Figure 2. Land use change in Sayung Sub-district in 2005 (a), 2009 (b) 2015 (c) and 2019 (d)

(Source : Digital Globe Imagery Visual Intepretation, 2019)

Furthermore, from the trend of change in land use from year 2005 - 2019 will be combined with population growth data to predict the land area in the Sayung Sub-district awakened. That is because of population growth in the region will have an impact on the space requirements for settlements resulting in increased undeveloped land. Based on the results of visual interpretation in times series increased by 226,00 hectar built area during the period 2005-2019, while the 
population has increased the number of population of 22.943 inhabitants and in 2025 is predicted to increase to 148.017 inhabitants. Based on both these data are then used to simulate the land area woke up in the study site because these parameters have a value that is linear, so in 2025 is predicted to land awaken in Sayung Sub-district around 1300,20 hectar. The following figure presents the correlation between the growth of population to built area in the Sayung Sub-district.

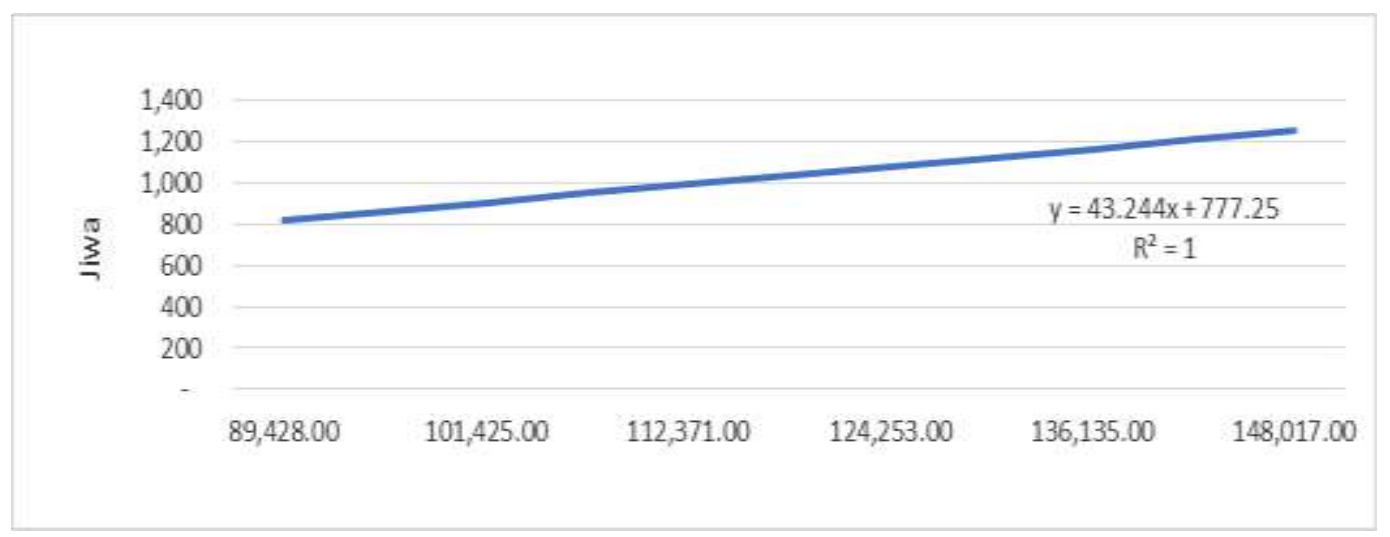

Figure 3. Correlation the population growth with Land use change in Sayung Sub-district

(Source : Analysis results, 2019)

As for the spatial distribution of built area using the model of cellular automata by using software LanduseSim 2.0, where the estimated distribution of spatial use two parameters of the controller, the highway and the center of community activities, it is based generally undeveloped land will be developed in the area there is access road and close with a community center. Increased undeveloped land will also be an impact on loss contributing to other uses, so that in this simulation predicted land use can be turned into smaller plots, among others: open field ,rice fields, vegetation non mangrove and mixed garden. The following picture presents a map of the land use cellular automata simulation results in 2025 and the spatial distribution of plots in the year 2005 to 2025 in the Sayung Sub-district. 

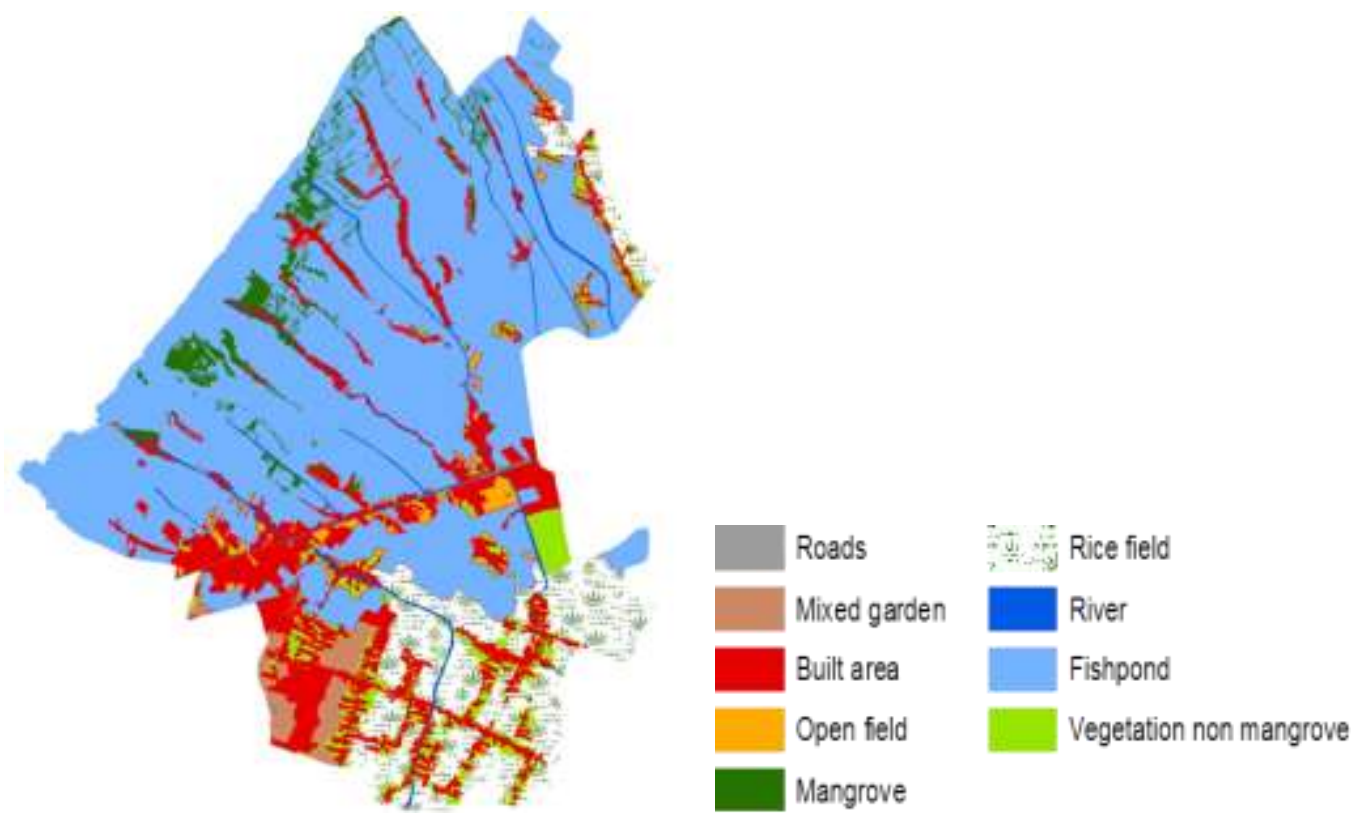

(E)

Figure 4. Land use prediction 2025 in Sayung Sub-district

(Source : Processing with cellular automata modelling, 2019)



(a)

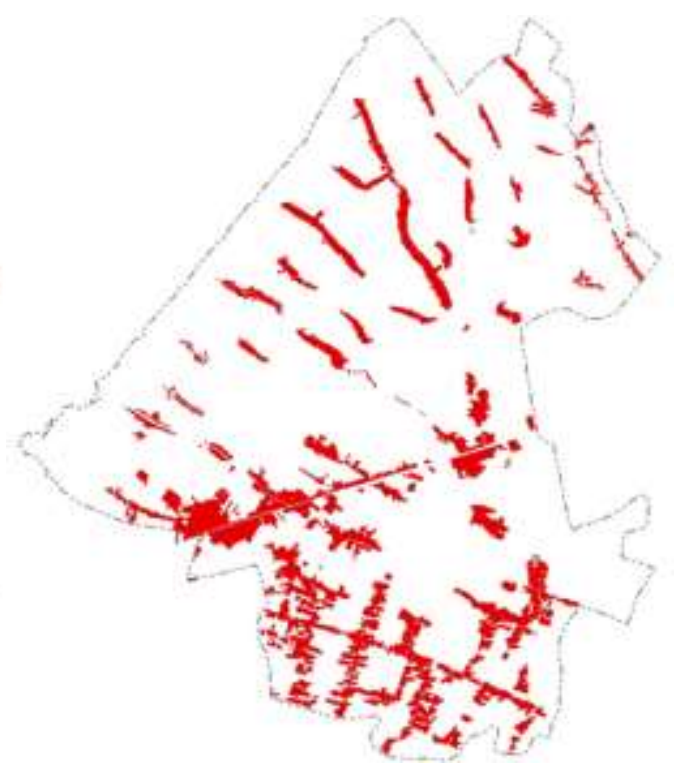

(b) 


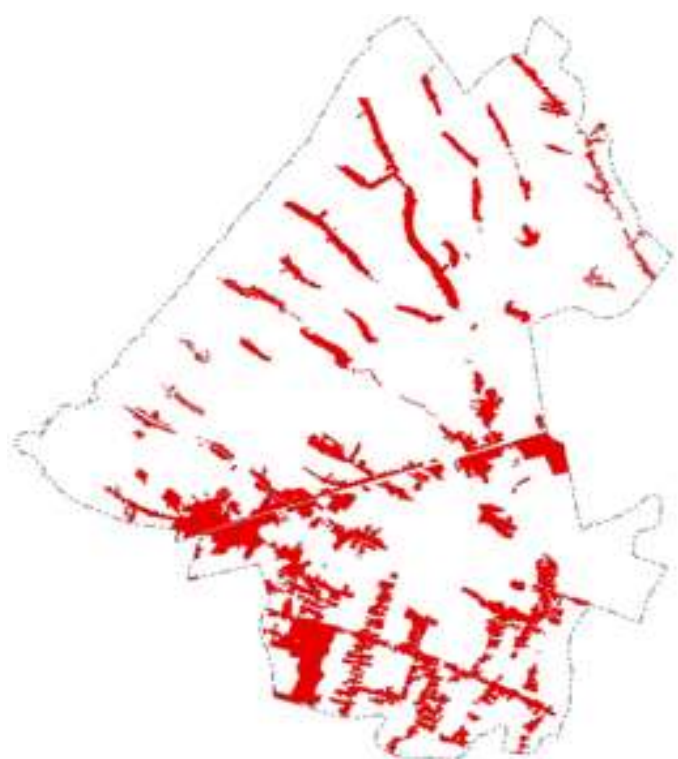

(c)

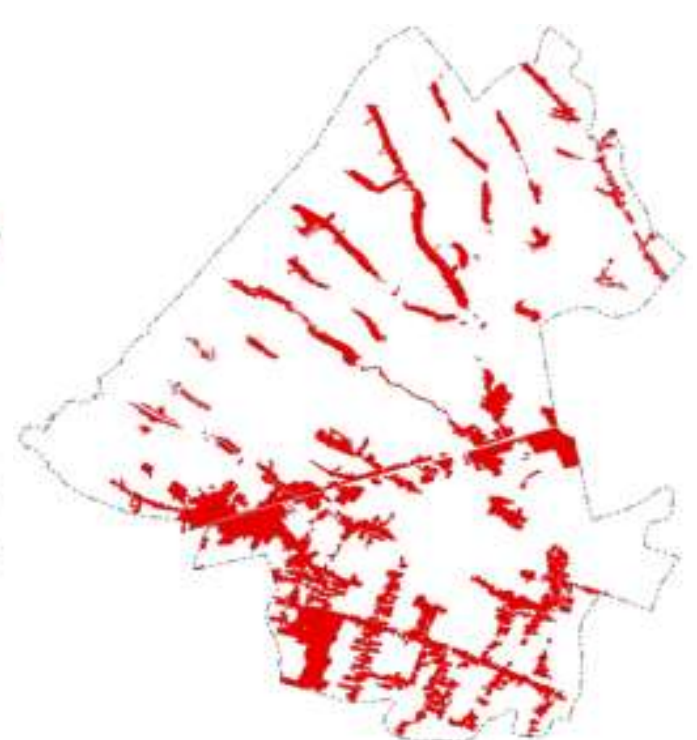

(d)

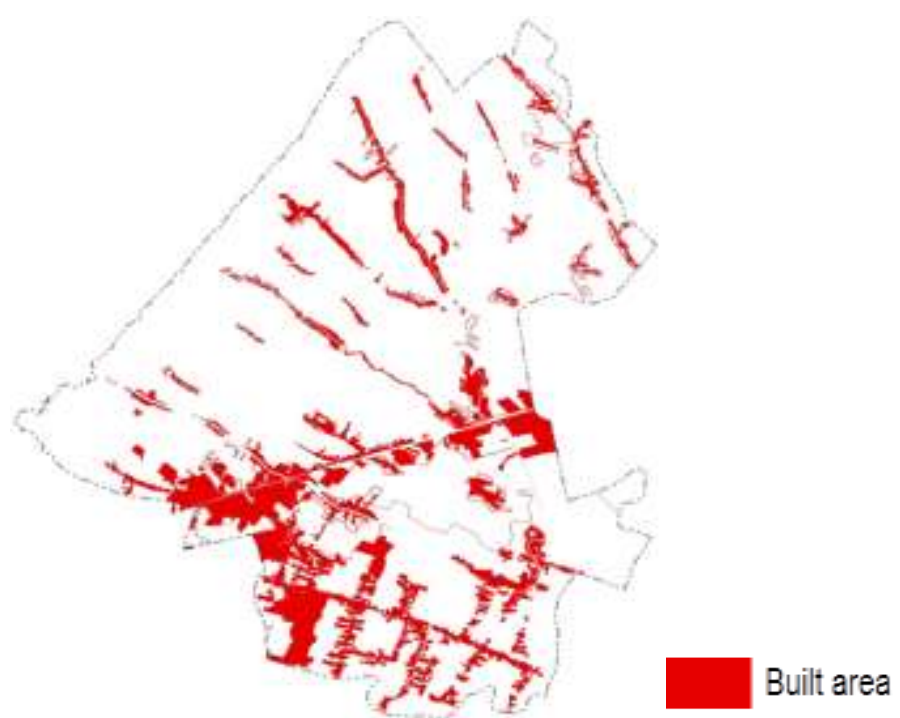

(e)

Figure 5. Spatial distribution built area 2005 (a), 2009 (b) 2015 (c),

2019 (d) and in 2025 in Sayung Sub-district

(Source : Digital globe imagery visual interpretation and simulation with cellular automata modelling, 2019) 
Based on the simulation results, it can be seen that the predicted growth of undeveloped land in the District of Sayung most have elongated pattern PANTURA way with an increase of 168,40 hectar. While the use of other land converted into built area among other lowland (106,44 hectar), open field (35.97 hectar), mixed garden (18 hectar) and vegetation non mangrove ( 8 hectar).

\section{Conclusions}

1. Based on the results of this study indicate that in the period 2005-2019 increasing land area of approximately 226,10 hectar awakened and widely predicted in 2025 reached 1300,21 hectar built area to the spatial distribution pattern PANTURA lengthwise along the way.

2. Increased land area in 2025 awakened an impact on the decrease in the extent of other land uses, where most rice fields converted 106.44 hectar, open field 35.97 hectar, mixed garden 18,00 hectar and vegetation non mangrove 8.00 hectar.

3. Modeling cellular automata with LandusSim 2.0 can be used to simulate land use change, and assist the planning

\section{References}

[1] R. S. Dewi, W. Bijker, A. Stein, and M. A. Marfai, "Fuzzy classification for shoreline change monitoring in a part of the Northern coastal area of Java, Indonesia," Remote Sens., vol. 8, no. 3, 2016.

[2] V. Siregar and A. F. Koropitan, "Corrigendum Corrigendum to 'Land Use Change and its Impact to Marine Primary Production in Semarang Waters, "' Procedia Environ. Sci., vol. 33, p. 674, 2016.

[3] A. Yuliyanti, D. Sarah, and E. Soebowo, "AMBLESAN TANAH DI DAERAH SEMARANG," Ris. Geol. dan Pertamb., vol. 22, pp. 93-104, 2013.

[4] I. Buchori, A. Sugiri, M. Mussadun, D. Wadley, and Y. Liu, "International Journal of Disaster Risk Reduction A predictive model to assess spatial planning in addressing hydro- meteorological hazards: A case study of Semarang City, Indonesia," Int. J. Disaster Risk Reduct., no. October, pp. 0-1, 2017.

[5] Husnayaen et al., "Physical assessment of coastal vulnerability under enhanced land subsidence in Semarang, Indonesia, using multi-sensor satellite data," Adv. Sp. Res., vol. 61, no. 8, pp. 2159-2179, 2018.

[6] H. Z. Abidin, H. Andreas, I. Gumilar, T. P. Sidiq, and Y. Fukuda, "Land subsidence in coastal city of Semarang (Indonesia): characteristics, impacts and causes," Geomatics, Nat. Hazards Risk, vol. 4, no. 3, pp. 226-240, 2013.

[7] A. W. Sejati, I. Buchori, and I. Rudiarto, "The Spatio-Temporal Trends of Urban Growth and Surface Urban Heat Islands over Two Decades in the Semarang Metropolitan Region,” Sustain. Cities Soc., p. 101432, 2019.

[8] A. Ismanto, A. Wirasatriya, M. Helmi, and A. Hartoko, "Model Sebaran Penurunan Tanah di Wilayah Pesisir Semarang," Ilmu Kelaut., vol. 14, no. 4, pp. 21-28, 2009. 
[9] Q. Geographicae and M. A. Marfai, "Impact of coastal inundation on ecology and agricultural land use case study in central Java , Indonesia," vol. 30, no. 3, pp. 19-32, 2011.

[10] E. Damastuti and R. De Groot, "Participatory ecosystem service mapping to enhance community-based mangrove rehabilitation and management in Demak, Indonesia," vol. $1800,2018$.

[11] I. Gumilar, H. Z. Abidin, H. Andreas, A. D. Mahendra, T. P. Sidiq, and M. Gamal, "STUDI POTENSI KERUGIAN EKONOMI ( ECONOMIC LOSSES ) AKIBAT PENURUNAN MUKA TANAH ( Studi kasus : Wilayah Jakarta , Bandung dan Semarang ), 2009.

[12] S. B. Iryanthony, M. Helmi, and P. A. Macklin, "Utilizing Landsat Satellite Data ( 19902018 ) to Detect Water Inundation for the Management of Human Settlements in Coastal Zones," vol. 12, no. June, 2019.

[13] I. Buchori, A. Pramitasari, A. Sugiri, M. Maryono, Y. Basuki, and A. W. Sejati, "Adaptation to coastal flooding and inundation: Mitigations and migration pattern in Semarang City, Indonesia," Ocean Coast. Manag., vol. 163, no. November 2017, pp. 445455, 2018.

[14] K. Islam, F. Rahman, and M. Jashimuddin, "Modeling land use change using Cellular Automata and Arti fi cial Neural Network: The case of Chunati Wildlife Sanctuary, Bangladesh," Ecol. Indic., vol. 88, no. January, pp. 439-453, 2018.

[15] B. Wijaya, H, H. Kurniawati, and S. T. E. W. Hutama, "Industrialization Impact on Worker Mobility and Land Use in Peri Urban Area ( Case study of Semarang District, Indonesia ) Industrialization Impact on Worker Mobility and Land Use in Peri Urban Area ( Case study of Semarang District, Indonesia)," 2018.

[16] M. A. Marfai, "The hazards of coastal erosion in Central Java , Indonesia : An overview," vol. 3, no. 3, pp. 1-9, 2011.

[17] A. Sowter, M. Bin Che Amat, F. Cigna, S. Marsh, A. Athab, and L. Alshammari, "Mexico City land subsidence in 2014-2015 with Sentinel-1 IW TOPS: Results using the Intermittent SBAS (ISBAS) technique," Int. J. Appl. Earth Obs. Geoinf., 2016.

[18] M. A. Marfai and L. King, "Potential vulnerability implications of coastal inundation due to sea level rise for the coastal zone of Semarang city, Indonesia," Environ. Geol., vol. 54, no. 6, pp. 1235-1245, 2008.

[19] T. Hu, J. Yang, X. Li, and P. Gong, "Mapping Urban Land Use by Using Landsat Images and Open Social Data," 2016.

[20] B. Rachmat, M. Helmi, and Hadiyanto, "Remote Sensing Applications: Society and Environment Analyzing spatiotemporal types and patterns of urban growth in watersheds that flow into Jakarta Bay, Indonesia," Remote Sens. Appl. Soc. Environ., vol. 14, no. October 2018, pp. 170-177, 2019.

[21] P. Rufin, H. Müller, D. Pflugmacher, and P. Hostert, "International Journal of Applied Earth Observation and Geoinformation Land use intensity trajectories on Amazonian pastures derived from Landsat time series," Int. J. Appl. Earth Obs. Geoinf., vol. 41, pp. $1-10,2015$.

[22] D. T. Town, S. Gondar, A. Halefom, A. Teshome, E. Sisay, and I. Ahmad, "Dynamics of Land Use and Land Cover Change Using Remote Sensing and GIS : A Case Study of," pp. 
165-174, 2018.

[23] I. Rizk and M. Rashed, "Monitoring urban growth and land use change detection with GIS and remote sensing techniques in Daqahlia governorate Egypt," Int. J. Sustain. Built Environ., vol. 4, no. 1, pp. 117-124, 2015.

[24] B. Rimal, Z. Lifu, K. Hamidreza, N. H. Barry, R. Sushila, and Z. Peng, "Land Use / Land Cover Dynamics and Modeling of Urban Land Expansion by the Integration of Cellular Automata and Markov Chain," 2018.

[25] M. N. Habibie et al., "Simulasi Rob Di Semarang Menggunakan Model Hidrodinamika 2D," J. Mkg, vol. 13, no. 2, pp. 103-109, 2012.

[26] A. L. Nugraha, P. B. Santosa, and T. Aditya, "Dissemination of Tidal Flood Risk Map Using Online Map in Semarang," Procedia Environ. Sci., vol. 23, no. Ictcred 2014, pp. 64-71, 2015.

[27] L. L. Coulter et al., "Remote Sensing of Environment Classi fi cation and assessment of land cover and land use change in southern Ghana using dense stacks of Landsat 7 ETM + imagery," Remote Sens. Environ., vol. 184, pp. 396-409, 2016.

[28] J. R. Otukei and T. Blaschke, "Land cover change assessment using decision trees, support vector machines and maximum likelihood classification algorithms," Int. J. Appl. Earth Obs. Geoinf., vol. 12, no. SUPPL. 1, pp. 27-31, 2010.

[29] A. M. Lubis, T. Sato, N. Tomiyama, N. Isezaki, and T. Yamanokuchi, "Ground subsidence in Semarang-Indonesia investigated by ALOS-PALSAR satellite SAR interferometry," J. Asian Earth Sci., vol. 40, no. 5, pp. 1079-1088, 2011.

[30] S. Mehvar, T. Filatova, I. Syukri, A. Dastgheib, and R. Ranasinghe, "Developing a framework to quantify potential Sea level rise-driven environmental losses: A case study in Semarang coastal area, Indonesia," Environ. Sci. Policy, vol. 89, no. February, pp. 216230, 2018. 